\title{
Socio-environmental survey of an ecologically important hamlet of Darjeeling district, West Bengal, India
}

\author{
S. Bhattacharya*, G. Ghosh, T. Banerjee, S. Goswami, P. Das \\ Department of Environmental Studies, Rabindra Bharati University, Kolkata, India \\ *E-mail address: sayan_evs@yahoo.co.in, sayan.evs@gmail.com
}

\begin{abstract}
Forest cover in hills is essential to maintain environmental, economic and ecological balances. North Bengal accounts for 3,086 sq km (26\%) of the 11,876 sq km area of classified forests in the state, and for nearly 5,000 sq km (40\%) of all land under tree cover. Upper Chatakpur is one of the emerging ecotourism spots of north Bengal, located at an altitude of 7887 feet in Darjeeling district. It is a 180 years old ethnic village with 19 houses and a population of about 89 , and at an altitude of $7887 \mathrm{ft}$. It is about $8 \mathrm{~km}$. from Sonada $\left(26^{\circ} 57^{\prime} \mathrm{N}, 88^{\circ} 16^{\prime} \mathrm{E}\right), 22 \mathrm{~km}$. from Darjeeling $\left(26^{\circ} 2^{\prime} \mathrm{N}, 88^{\circ}\right.$ $\left.15^{\prime} \mathrm{E}\right)$ and $72 \mathrm{~km}$. from Siliguri $\left(26^{\circ} 42^{\prime} \mathrm{N}, 88^{\circ} 25^{\prime} \mathrm{E}\right)$. Upper Chatakpur Village situated within Senchal Wildlife Sanctuary, Darjeeling. The sanctuary with an area of $38.88 \mathrm{sq}$. km has an elevation of 1500-2600 m. The survey work was done in December, 2014 by visiting upper Chatakpur village and the primary data were gathered through field survey and direct contact with common people and authorized centers of the region. Surveys on the topography, demography, agriculture, livestock, water management, education, culture, health, waste management, transport, biodiversity, human animal conflict were done in this area. Medicinal plant diversity was studied in the village area and information was gathered from the local forest department centre. Information regarding the transport system was collected from the local transport office and syndicate. Census report was collected from the Sonada Panchayat Office. Health and education information was collected from the local primary school and the local sub health centre. Information on sustainable agricultural practices and waste management policies is collected through surveys in the village houses and agricultural fields. Biodiversity of Senchal Wildlife Sanctuary was documented by visiting the forest areas. Pictorial documentation was done in every phase of study. In spite of getting so much attention in the recent time, the village is not adequately developed. There is an urgent need for implementing sustainable management systems in the areas for the betterment of the socio-environmental structures. Some of the possible management strategies have been suggested for maintaining the social, environmental, economic and ecological balance of the region.
\end{abstract}

Keywords: Chatakpur; North Bengal; Survey; Management; Biodiversity; Environment

\section{INTRODUCTION}

Forest cover in hills is essential to maintain environmental, economic and ecological balances. North Bengal accounts for 3,086 sq km (26\%) of the 11,876 sq km area of classified forests in the state, and for nearly $5,000 \mathrm{sq} \mathrm{km}(40 \%)$ of all land under tree cover. 
The most forested areas are located in Darjeeling and Jalpaiguri, which have 2,994 sq $\mathrm{km}$ of classified forests and 4,614 sq km of forested land under all forms of ownership [1].

Upper Chatakpur has now become an emerging ecotourism destination for people living on the coast of West Bengal. Upper Chatakpur is one of India's secret, small remote unexplored hill rich in biodiversity and indigenous cultures. It is a small village located in the eastern part of the Himalayan Range, in the north of West Bengal at $7887 \mathrm{ft}$. altitude. It is a 180 years old ethnic village with 19 houses and a population of about 89 . It is about $20 \mathrm{~km}$. from Darjeeling and $72 \mathrm{~km}$. from Siliguri [2]. On the northern side, it is surrounded by the Mt. Kanchenjunga and on the southern side the undulating green valley and the meandering river gorge of Relly Khola resides. Weather in summer is pleasant, average temperature is around 12-25 degree. In winter average temperature is 2- 12 degree and snow fall is common here [1]. The Locals belong to either "Rai Community" or "Sherpa Community". The terrace cultivation of organic crops and the shrubs and medicinal herbs acquired from the forest, form the means of livelihood of the locals. The place offers majestic views of Mt. Kanchenjungha, lush greenery, forest trails and wooden cottages and in short, is an ideal destination for those seeking peace and tranquility in the Himalayas. In terms of its location and view, Chatakpur is comparable to Tiger Hill, the sunrise point of Darjeeling. Although there is no overnight accommodation at Tiger Hill, Chatakpur has some tourist accommodation available, leading to its increasing popularity.

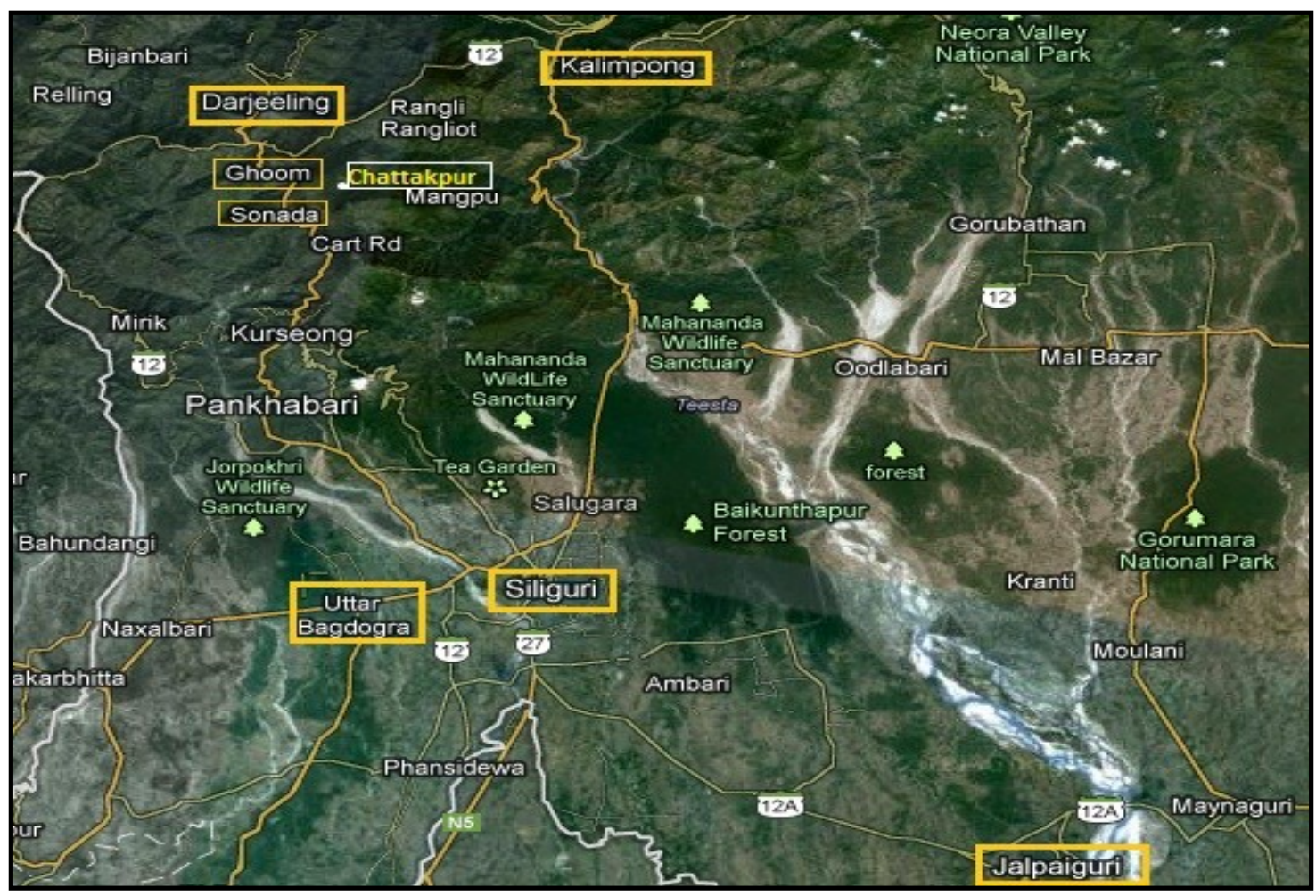

Figure 1a. Map showing the position of Chatakpur village. 


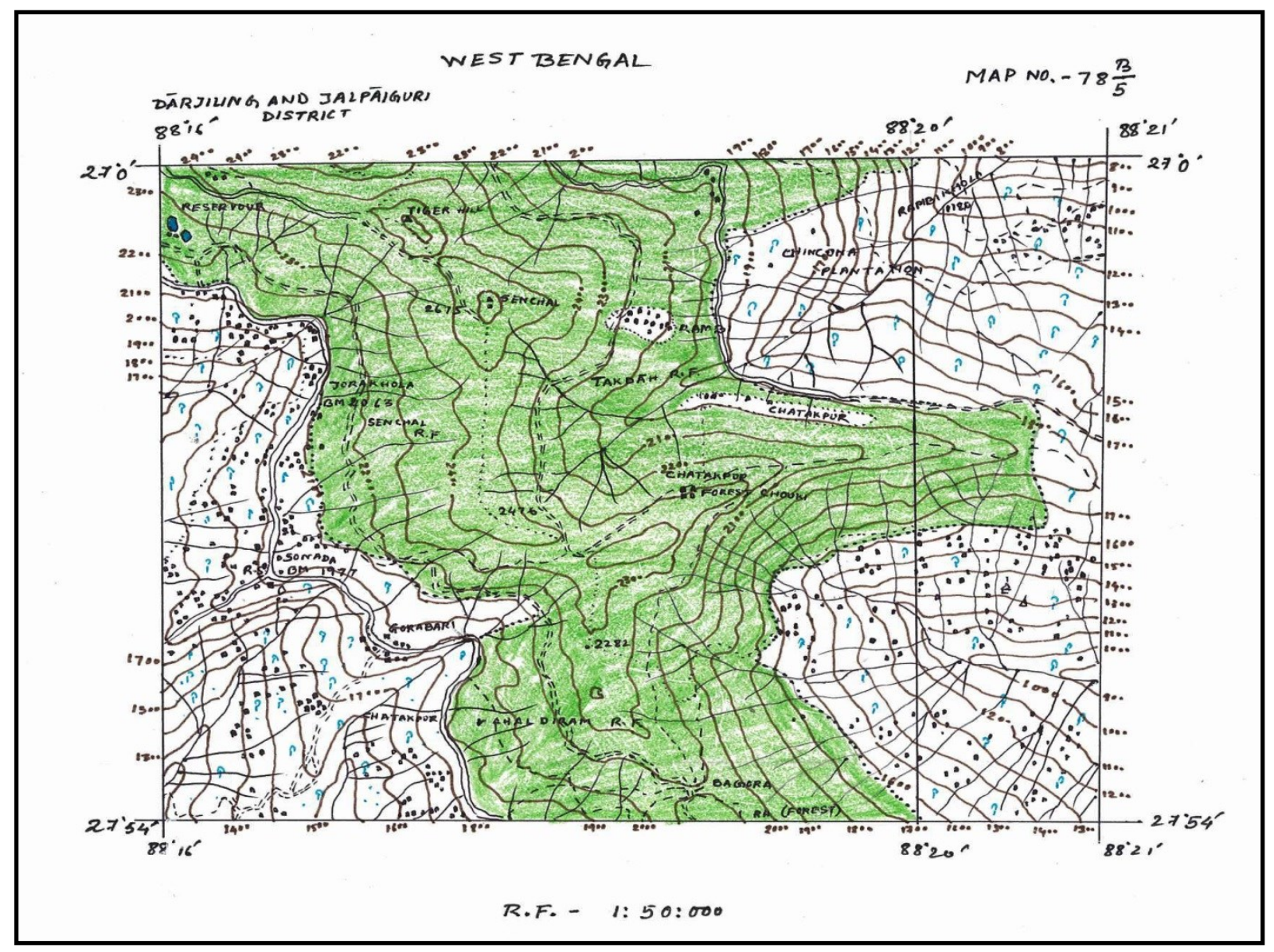

Figure 1b. Topographical Map of Chatakpur area and Senchal Wildlife Sanctuary.

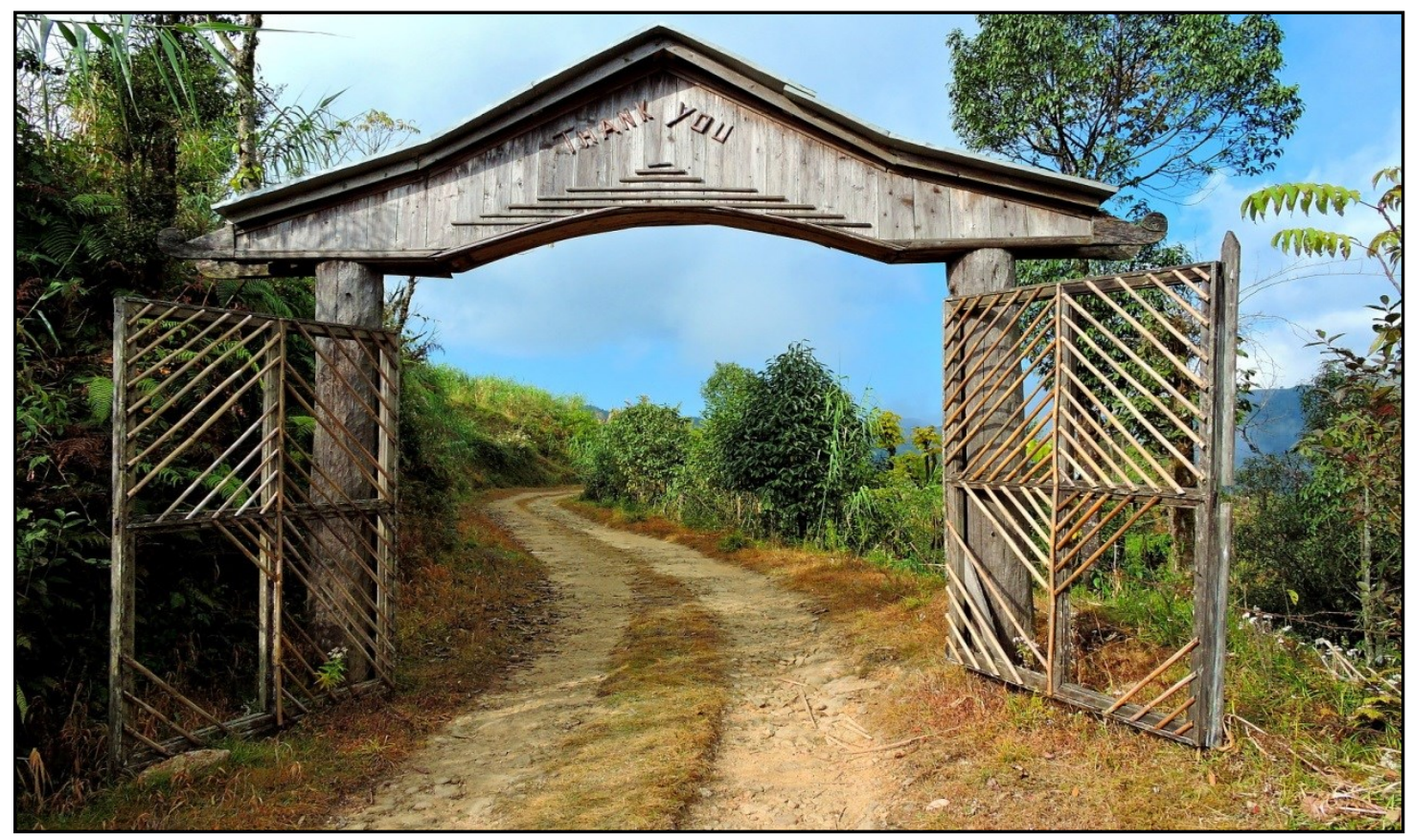

Figure 2. Entrance of Chatakpur Village. 


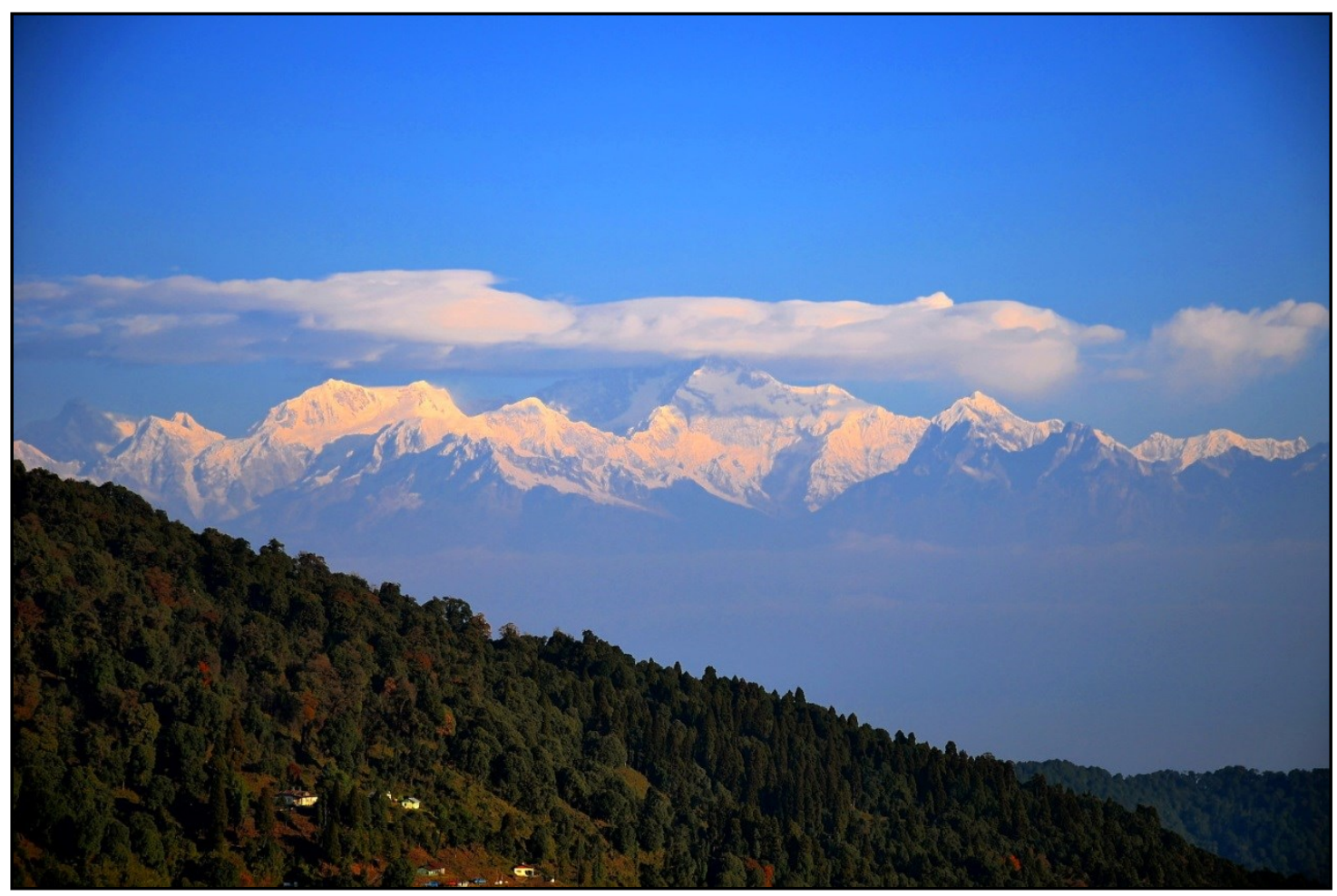

Figure 3. View of Kangchenjunga from Chatakpur Village.

Upper Chatakpur Village situated Within Senchal Wildlife Sanctuary, Darjeeling. The sanctuary with an area of 38.88 sq. $\mathrm{km}$ has an elevation of 1500-2600 m. Surrounded by high mountains Senchal receives a very heavy amount of precipitation. Also the Sanctuary is crisscrossed by number of streams and Jhoras [3]. Such a water rich situation has made this Sanctuary the water supply source for Darjeeling Town. The Senchal Lake is the main reservoir of this supply.

Figure 1a shows the position of Chatakpur village, Figure 2a shows the topographical sheet of Chatakpur area and the Senchal Wildlife Sanctuary (map collected and prepared from National Atlas and thematic mapping organization, Kolkata Office, West Bengal). Figure 2 shows the entrance to Chatakpur village and Figure 3 shows the beautiful view of Kangchenjunga from Chatakpur Village.

\section{METHODS OF THE SURVEY WORK}

The study was done in December, 2014 by visiting upper Chatakpur village and the primary data were gathered through field survey and direct contact with common people and authorized centers of the region. Information on agricultural activities is collected from the local villagers. Medicinal plant diversity was studied in the village area and information was gathered from the local forest department centre. Information regarding the transport system was collected from the local transport office and syndicate. Census report was collected from the Sonada Panchayat Office. Religious and social festival information was collected from the local people. Health and education information was collected from the local primary and high schools and the local sub health centre. Information on environmental activities like using 
sustainable agricultural practices and waste management policies is collected through surveys in the villages and from the local hotels situated at upper Chatakpur. Pictorial documentation was done in every phase of study $[4,5]$.

\section{POPULATION STRUCTURE}

At Upper Chatakpur village, there are only 19 houses with total population of 89 people. The census report of 2011 was collected from Sonada Gram Panchayat Office, situated $8 \mathrm{~km}$. far from Chatakpur Village. The census data is represented in table 1. Male female ratio and literate illiterate ratios are shown in chart 1 and 2.

Table 1. Population Census data (2011) of Chatakpur Village.

\begin{tabular}{|c|c|c|c|c|c|c|c|}
\hline $\begin{array}{c}\text { Total } \\
\text { Population }\end{array}$ & $\begin{array}{l}\text { No. of } \\
\text { Males }\end{array}$ & $\begin{array}{c}\text { No. of } \\
\text { Females }\end{array}$ & No. 0 & iterates & No. of & literates & $\begin{array}{l}\text { Below } 6 \text { years } \\
\text { children }\end{array}$ \\
\hline \multirow{2}{*}{89} & \multirow{2}{*}{45} & \multirow{2}{*}{44} & \multicolumn{2}{|c|}{77} & & 2 & \multirow[b]{2}{*}{ 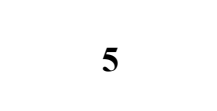 } \\
\hline & & & Male $=\mathbf{3 7}$ & Female $=40$ & Male $=8$ & Female $=4$ & \\
\hline
\end{tabular}

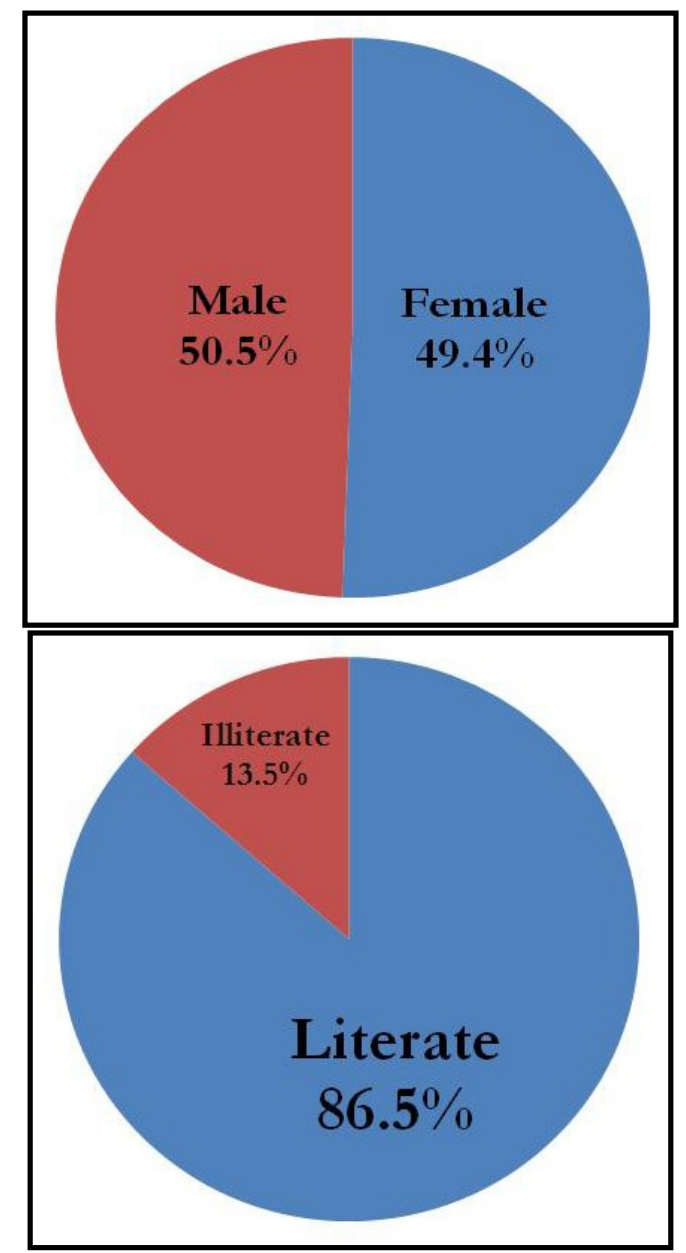

Chart $1 \&$ 2. Shows the male female ratio and literate illiterate ratio. 


\section{AGRICULTURE AND LIVESTOCK}

In the hill areas of upper Chatakpur, terrace cultivation or step cultivation is practiced (Figure 4). It is method of growing crops on sides of hills or mountains by planting on graduated terraces built into the slope. Though labour-intensive, the method has been employed effectively to maximize arable land area in variable terrains and to reduce soil erosion and water loss [5]. In some place, local green houses are made for cultivation (Figure 5). Pig fencing was observed in the agricultural fields.

In upper Chatakpur, the common cultivable edible plants are potato, garlic, ginger, cauliflower, cabbage, beans, radish, carrot, coriander, green peas, spinach, Fenugreek leaves, squash, leaf mustard etc. The people of upper Chatakpur usually practiced organic farming, cowdung is used as manure. No pesticide and fertilizer is added to the fields as there is no pest attack in the agricultural areas. Most of the houses in upper Chatakpur have cultivable lands adjacent to the houses and farming is done there. Agricultural production is one of the main economic sources of the people in upper Chatakpur. They used to sell the foods in the markets after production. Honey production is also an important source of earning. The inhabitants used to make artificial wooden structures in which bees take shelter and store honey. They periodically collect the honey and supply it to market.

The common livestock at upper Chatakpur are local breeds of cows. Local poultry farms are found in many houses. Meat, eggs and milk are the main livestock products which are among the important economic sources.

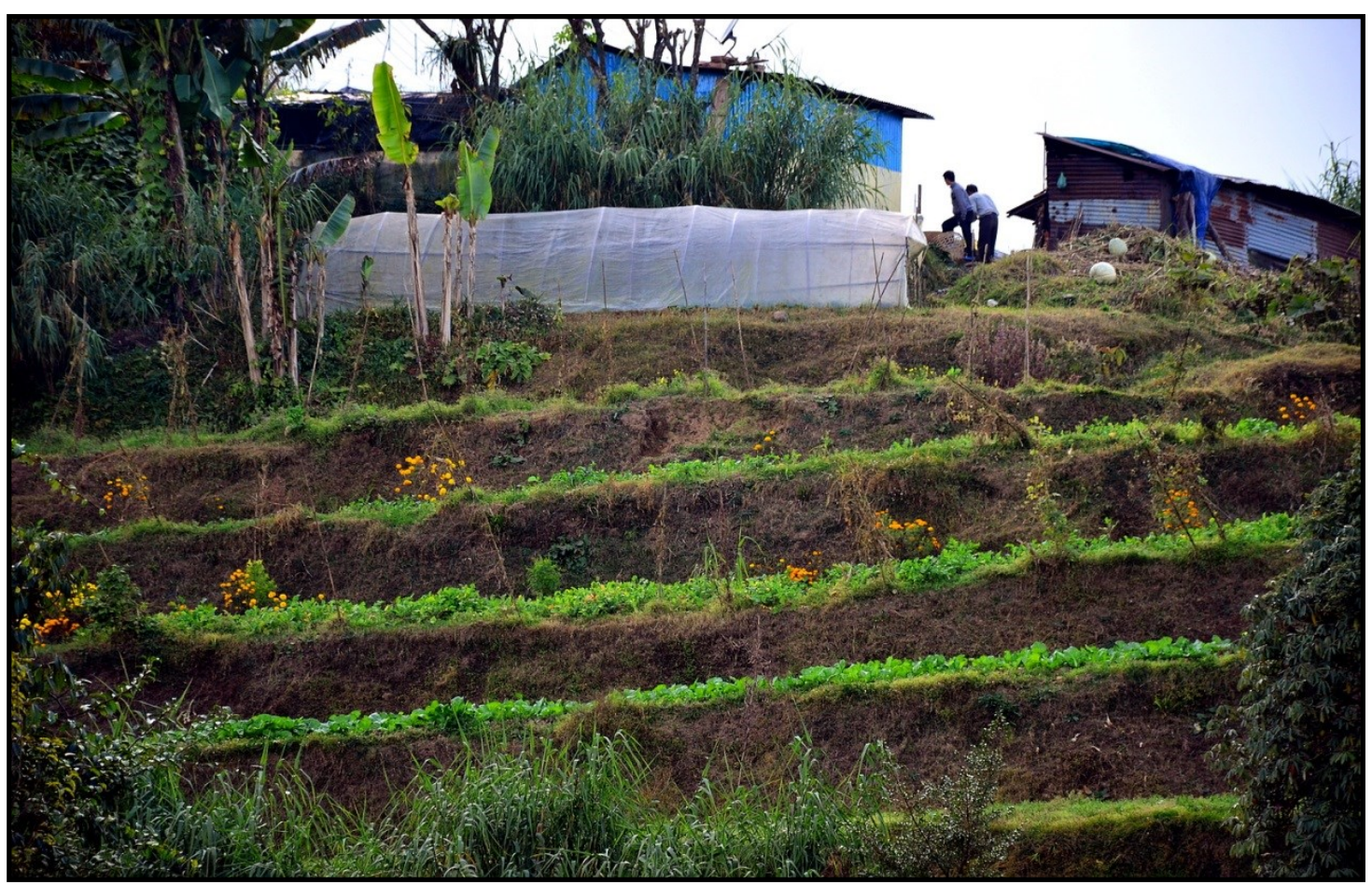

Figure 4. Step cultivation process at Chatakpur Village. 


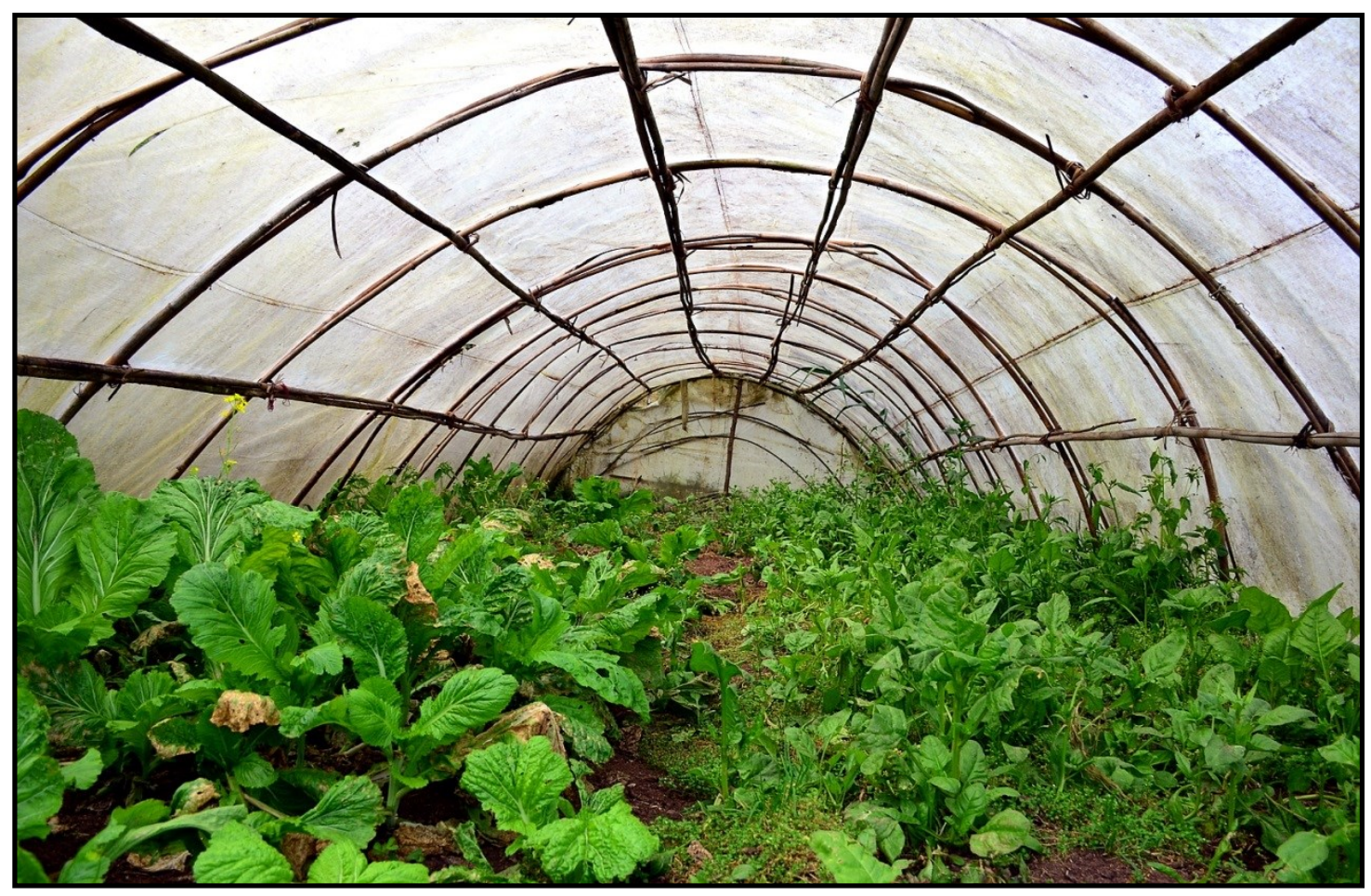

Figure 5. Agriculture in green house at Chatakpur Village.

\section{WATER MANAGEMENT}

The main water source of upper Chatakpur is the water coming from the hills through channels like "jhoras". An artificial cistern is made to collect and store the hill water. The cement made cistern is situated in the forest, around $1 \mathrm{~km}$. away from upper Chatakpur village. Network of pipeline distributes the water from the cisterns to the houses. Each house has its own water collecting and storing unit from which they get the supply. Additionally, people used to bring water from the water sources in the hills (local "jhoras") during the period of water crisis in February, March and April. In the houses, roof top rainwater harvesting structures were observed. The roofs have aluminium gutters (long, hollow device that is attached to the edges of the roof to catch rain and carry it away from a building) at the corner for collecting rainwater. The roofs have inclined slope, so that water flows easily in the gutter. The rainwater falling on the roof top can be collected through these gutter channels. Pipes are connected with the gutters through which water can be collected in the cisterns and containers [4]. The collected rainwater is used for bathing, washing and drinking purpose. For irrigation, people entirely depend on rainwater. Figure 6 shows the rainwater harvesting process at Chatakpur Village.

Similar kind of rainwater harvesting structures were observed in our two previous surveys of North Bengal (in Lava, Rishop and Tinchuley), where periodical water stress occur $[4,5]$. 


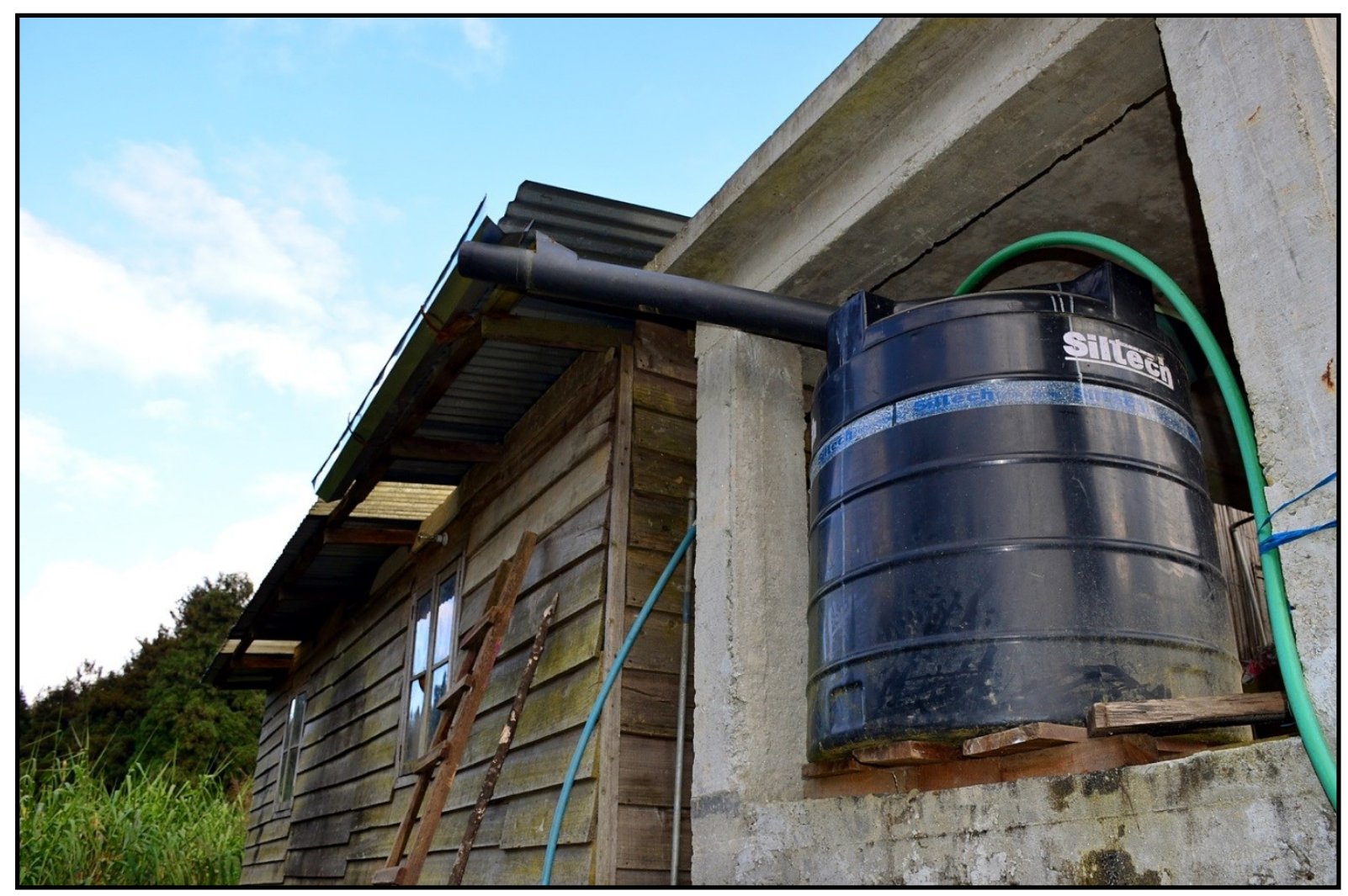

Figure 6. Roof top rainwater harvesting process at Chatakpur Village.

\section{WASTE MANAGEMENT}

In upper Chatakpur, the common waste materials generated are solid wastes, including plastic packets, paper boxes, plastic bottles, glass bottles, vegetable wastes etc. Solid wastes are usually collected in specific bins. Every house their own burning places where they used to burn all the solid wastes. The unburned materials are buried in the ground. However, burial of the wastes, specially the hazardous ones, and burial of the wastes can affect the sensitive ecosystems of those areas, and can affect the inhabitants as well. Plastic and glass bottles are generally recycled by selling in the local markets after use. Figure 7 shows the collection of solid wastes at Chatakpur village. 


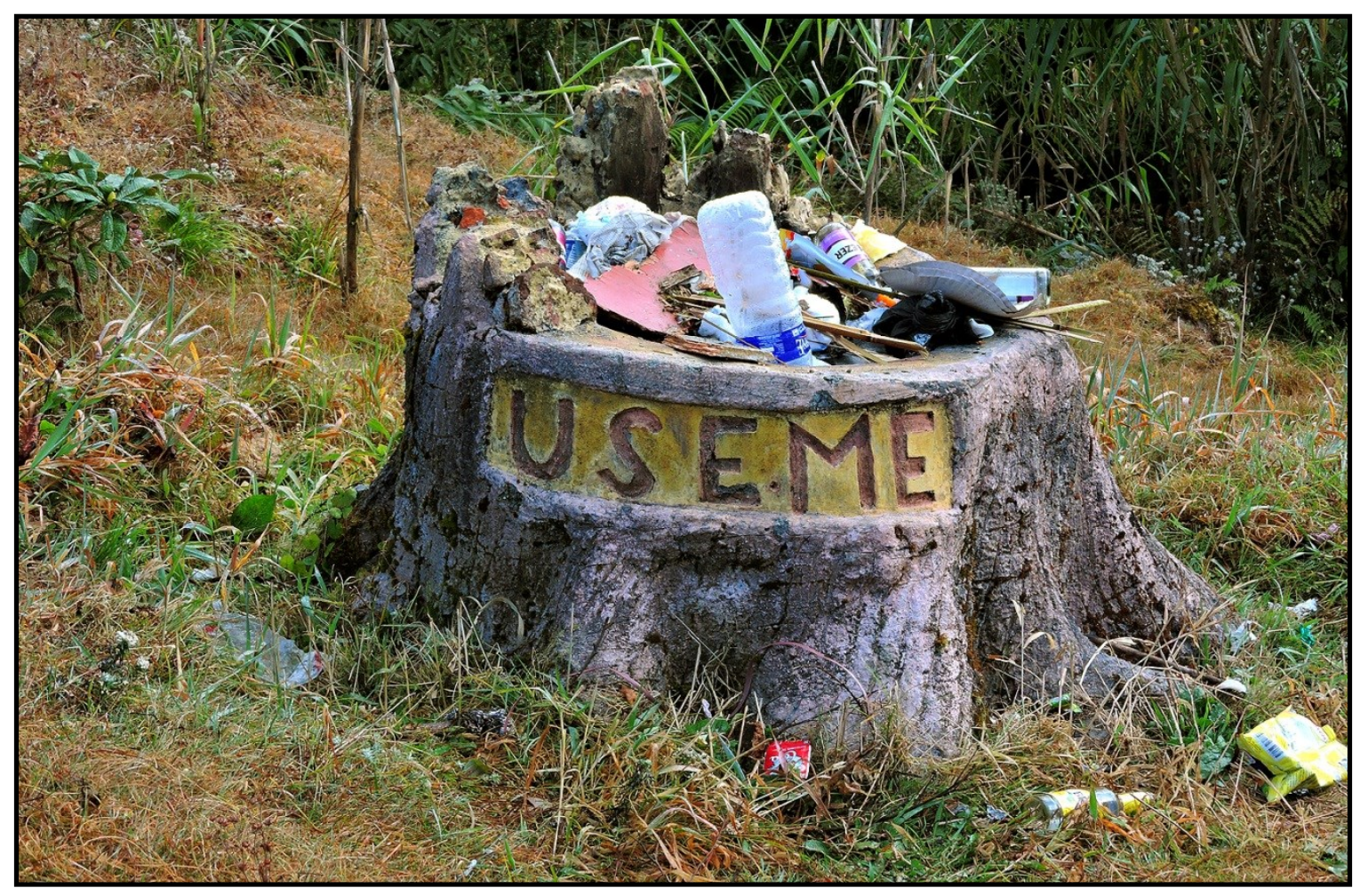

Figure 7. Collection of solid wastes at Chatakpur village.

\section{EDUCATION, CULTURE AND HEALTH}

There is only one primary school in upper Chatakpur, Chatakpur forest Primary school (Figure 8), which was established in 1958. The classes are upto forth standard. Only two teachers are in that school, while the number of students is only four. The school syllabus includes English, Nepali language, environmental studies, arithmetic, geography, science, general knowledge and drawing. For higher studies, people of upper Chatakpur usually go to the high schools of Sonada ( $8 \mathrm{~km}$. far from upper Chatakpur) and the schools and colleges of Darjeeling (22 km. far from upper Chatakpur).

Interestingly, there is no specific medicine shop in upper Chatakpur. There is only one small stationary shop in the area, where basic medicines are available. People used to go to Sonada Primary Health Centre and Darjeeling District Hospital for treatment purpose. In Sonada Health Centre, two doctors are available with nurses. No operation facilities are available in Sonada, people have to visit the district hospital for operation and emergency cases.

In upper Chatakpur, local food products are completely based on agricultural products and livestock products. Delicacies are Rice, Tibetan - chicken and pork steamed momo, Thuppa, Gunruk Soup, Chimping Chuttney and a green Chilly Chuttney made of "Dalle"which is famous for its aroma. Local drinks are Guras ,Roxy, Channg, Thomba [2].

In Chatakpur, the main festivals are Dasara, Diwali and Losar. Losar is the Buddhist festival ("Losar" in Tibetan language means New Year), which is celebrated for 15 days, however, the main celebration occurs in the first three days. 


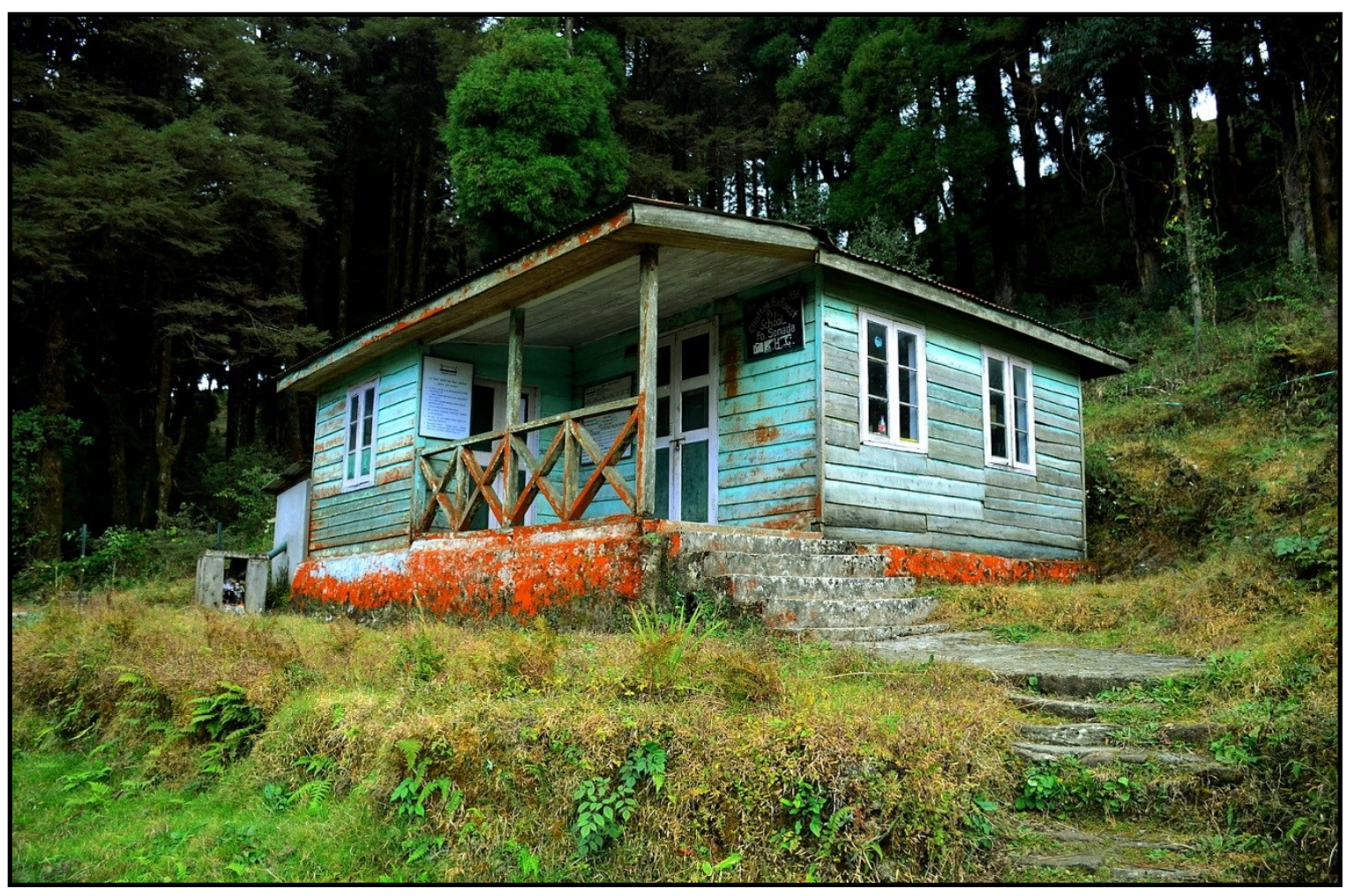

Figure 8. Chatakpur forest Primary school.

\section{DISASTERS}

Darjeeling valleys are under rapid habitat destruction due to several anthropogenic pressures and developmental activities like hydro-electrical projects, development of roads, establishment of tea gardens, mining and quarrying, landslides, forest fire etc. These factors jointly have increased the fragility of the Himalayan Mountains, leading to an increase in the incidence of landslides in the region. In upper Chatakpur, road side small landslides are very common. Besides, the area is also earthquake prone [6]; small earthquake incidences are experienced in upper Chatakpur frequently.

\section{TRANSPORT AND CONNECTIVITY}

In public transports, there is only one private car in upper Chatakpur which connects the area with Sonada and Darjeeling. Every morning, the car carries passengers going to Sonada on sharing basis. However, tourist can visit upper Chatakpur by hiring car from Siliguri, New Jalpaiguri, Darjeeling, Sonada and other places of North Bengal and Sikkim. Upper Chatakpur is connected with places of Bengal and Sikkim like Siliguri, New Jalpaiguri, Gorumara forest, Lataguri forest, Murti (dooars area), Hollong, Bagdogra, Darjeeling, Malbazar, Odlabari, Tinchuley, Gangtok, Pelling, Mirik, Ravangla, Gorubathan, Kalimpong, Jorethang, Pedong, Rangpoo, Kersiong etc. Car is the only mode of transport, especially in case of sightseeing purpose.

From upper Chatakpur, short Trekking are arranged such as $6 \mathrm{~km}$ trekking to Mongpo, $12 \mathrm{~km}$ trekking to Tiger Hill, and $8 \mathrm{~km}$ trekking to Rambi village. Nearby places are Rambi village, Sonada, Bagora Airforce, Darjeeling,Sukhiapokhri,lepchajagat. 


\section{ECONOMY}

Agriculture is one of the main economic sources of the inhabitants of upper Chatakpur. The people used to sell the agricultural and livestock products in the local markets of Sonada and Darjeeling. Additionally, some of the local people earn money by guiding the tourist. They help in bird watching, trekking, rock climbing, butterfly study and in the identification of the common medicinal plants of upper Chatakpur. Among the total population of upper Chatakpur, 9-10 young individuals migrated outside for jobs and business purpose. The monthly income of the families living in upper Chatakpur varies between 3000 to 15000 INR. Crop husbandry, animal husbandry, wild biodiversity and rural economy are subsystems of the integrated traditional resource management system.

\section{MAN ANIMAL CONFLICTS}

Human-Wildlife Conflict (HWC) occurs when wildlife requirements overlap with those of human populations, creating costs both to residents and wild animals [7]. Man-animal conflict has been in existence for as long as humans have existed and wild animals and people have shared the same landscapes and resources [8]. Direct contact with wildlife occurs in both urban and rural areas, but it is generally more common inside and around Protected Areas. With increasing population and pressure on forest areas, human-wildlife interaction and resultant conflict is also increasing [9]. Sikkim and Darjeeling, being a part of a global biodiversity hotspot [10], has diverse fauna which live in close proximity to human beings. Sikkim and Darjeeling have a high concentration of Protected Areas. Majority of conservation efforts are focused in these protected areas with a predominant paradigm of conservation in islands with little attention to corridor connectivity and integrity. Communities living in and around Protected Areas are not included as primary stakeholders. In many instances, these communities are highly marginalized and living in difficult circumstances.

In upper Chatakpur, the man animal conflict is mainly centered on the attacks of bears and wild boars in the agricultural fields. One of the main reasons for conflict between bears and humans in Senchal wildlife sanctuary is because of locals venturing into the sanctuary to collect fodder for their livestock [11]. Pig fencing was observed which is specially made for protecting the crops from wild pigs. Goat is generally not managed as livestock, as there is risk of leopard attacks on the goats. Wild bears rarely attack the local inhabitants. However, no local report was found about the attack of leopard on human population.

\section{BIODIVERSITY}

\section{Senchal Wildlife Sanctuary (SWS)}

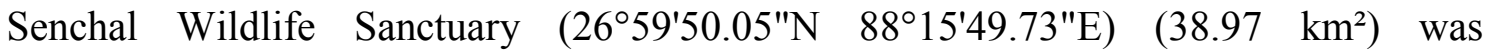
established in 1915 and is situated at a distance of $11 \mathrm{~km}$ from Darjeeling town. The area of the sanctuary is approximately $38.97 \mathrm{~km}^{2}$. The area was declared a wildlife sanctuary vide notification No. 5380-F, dated $24^{\text {th }}$ June, 1976 [12]. It is one of the five important Protected Areas of Darjeeling district. The two famous lakes of Senchal supply portable water to Darjeeling city [11].

The temperature during the cold season varies from 1.7 degree $\mathrm{C}$ and 8.4 degree $\mathrm{C}$ and during the hottest period, it varies between 14.4 degree $\mathrm{C}$ and 18.9 degree $\mathrm{C}$. Frost is very common from December till March in areas above 2000m, in high ridges, snowfall can be experienced [13]. 
There are 19 major settlements within as well as in areas adjoining the forest, with Ghoom-Jore Bungalow being the largest among them. The Sanctuary has 19 blocks under two ranges. The Sanctuary also contains the catchment area for the water supply of the city of Darjeeling. Many roads and public thoroughfares penetrate the Sanctuary and significantly influence the sanctity of the Sanctuary [11]. Figure 9 shows the Senchal sanctuary at Chatakpur and Figure 10 shows the Kanchenjunga Landscape, corridors with Senchal Sanctuary.

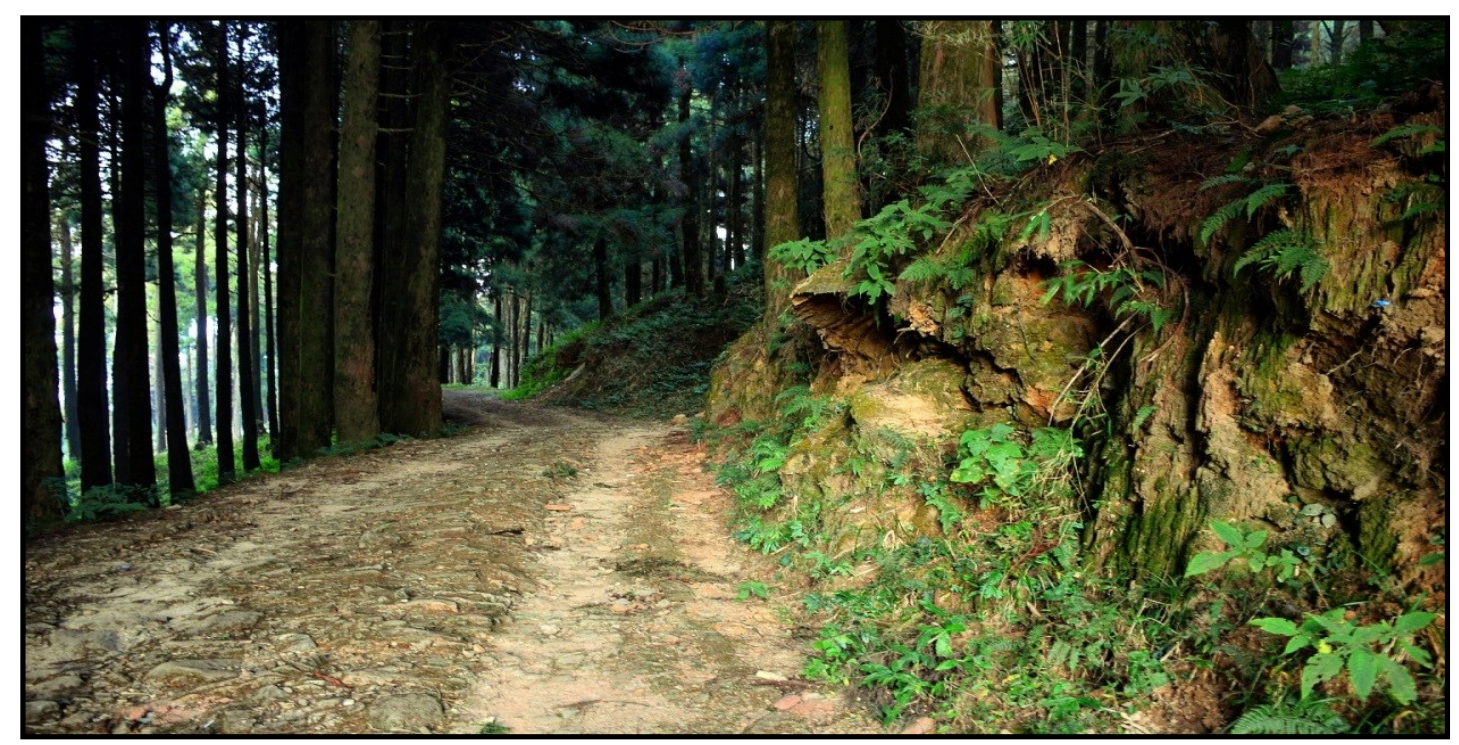

Figure 9. Senchal Wildlife Sanctuary at Chatakpur.

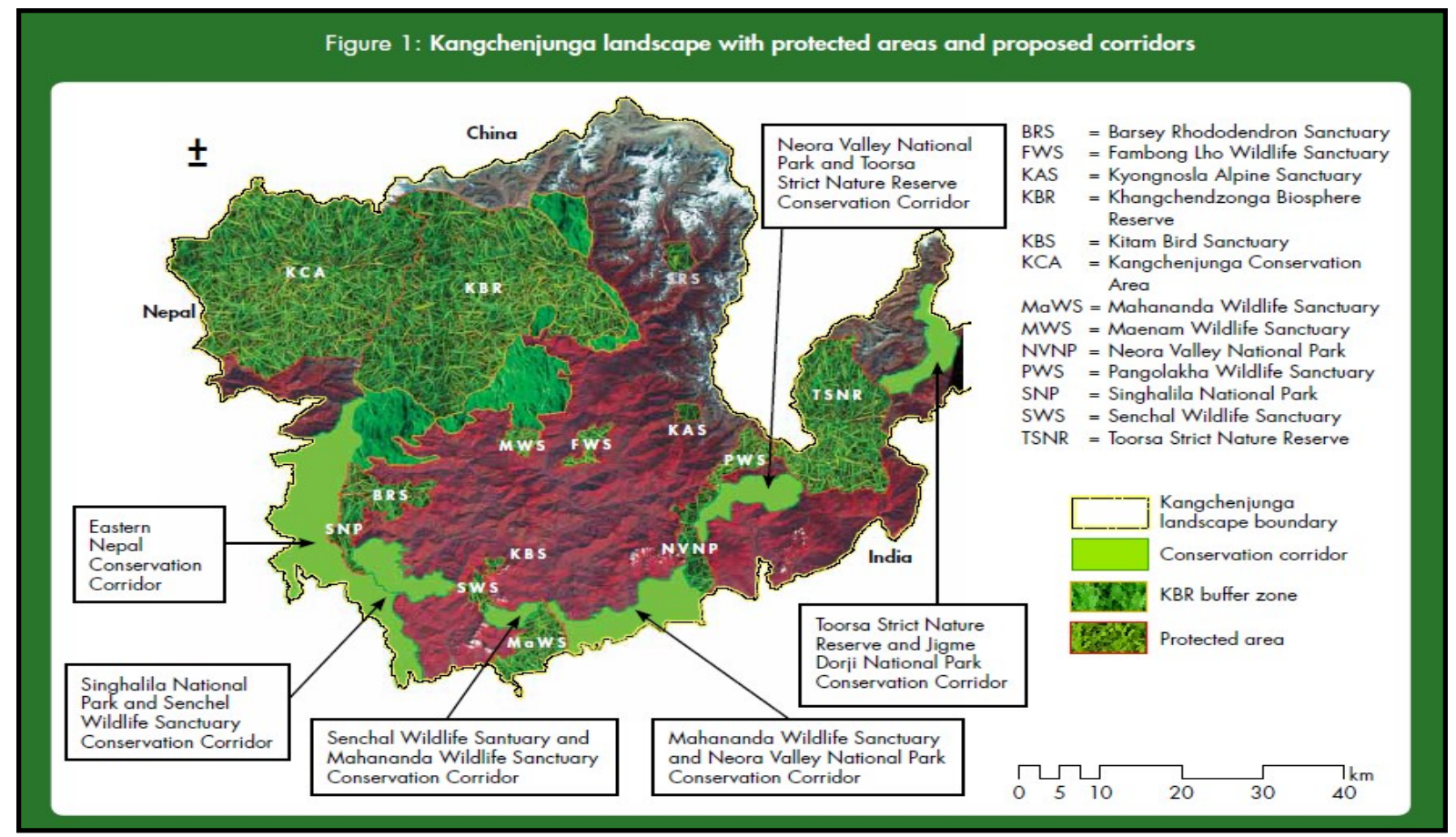

Figure 10. Kangchenjunga Landscape with protected areas and proposed corridors [13]. 


\section{Floral diversity of SWS}

Altitudinally, the sanctuary ranges between $1500-2600 \mathrm{~m}$. and broadly houses subtropical and temperate oak forests. Approximately 380-400 flowering plants can be found in Senchal Wildlife Sanctuary. The Sanctuary is home to various species of Rhododendron, Michelia, Oak, Pine and Birch. A large number of Hydrangeas, Orchids, Daphne and Mahonia can also be found [14]. The background vegetation is temperate broad-leaved forest with dominant species such as, Rhododendron arboreum, Rhododendron grande, Castanopsis hystrix, Ilex sikkimensis, Magnolia campbellii, Alcimandra cathcartii, Exbucklandia populnea, and Prunus cerasoides. Climbers and scramblers include Rubus paniculatus, Senecio diversifolius, Rubia manjith, Codonopsis viridis, and Edgaria darjeelingensis. The undershrubs and herbs are dominated by Aconogonum molle, Cautleya lutea, Globba hookeri, Artemisia vulgaris, Urtica dioica, and Gerardiana heterophylla [15]. The major vegetation type is moist temperate forest, which supports many large mammals. The secondary grassland on Tiger Hill is home to innumerable sun-loving herbaceous plants. Being an area with very high humidity, almost all trees, including planted conifers, are covered with thick epiphytic vegetation, including Begonia gemipara, Agapetes serpens, Acer hookerii, Pilea ternifolia, Chamabainia cuspidata, and Hymenodictyon flaccidum. The sanctuary is also home to numerous medicinal plants such as Swertia chirayita, S. pedicillata, Panax pseudoginseng, Hypericum uralaum, and Valleriana hardwickii [15].

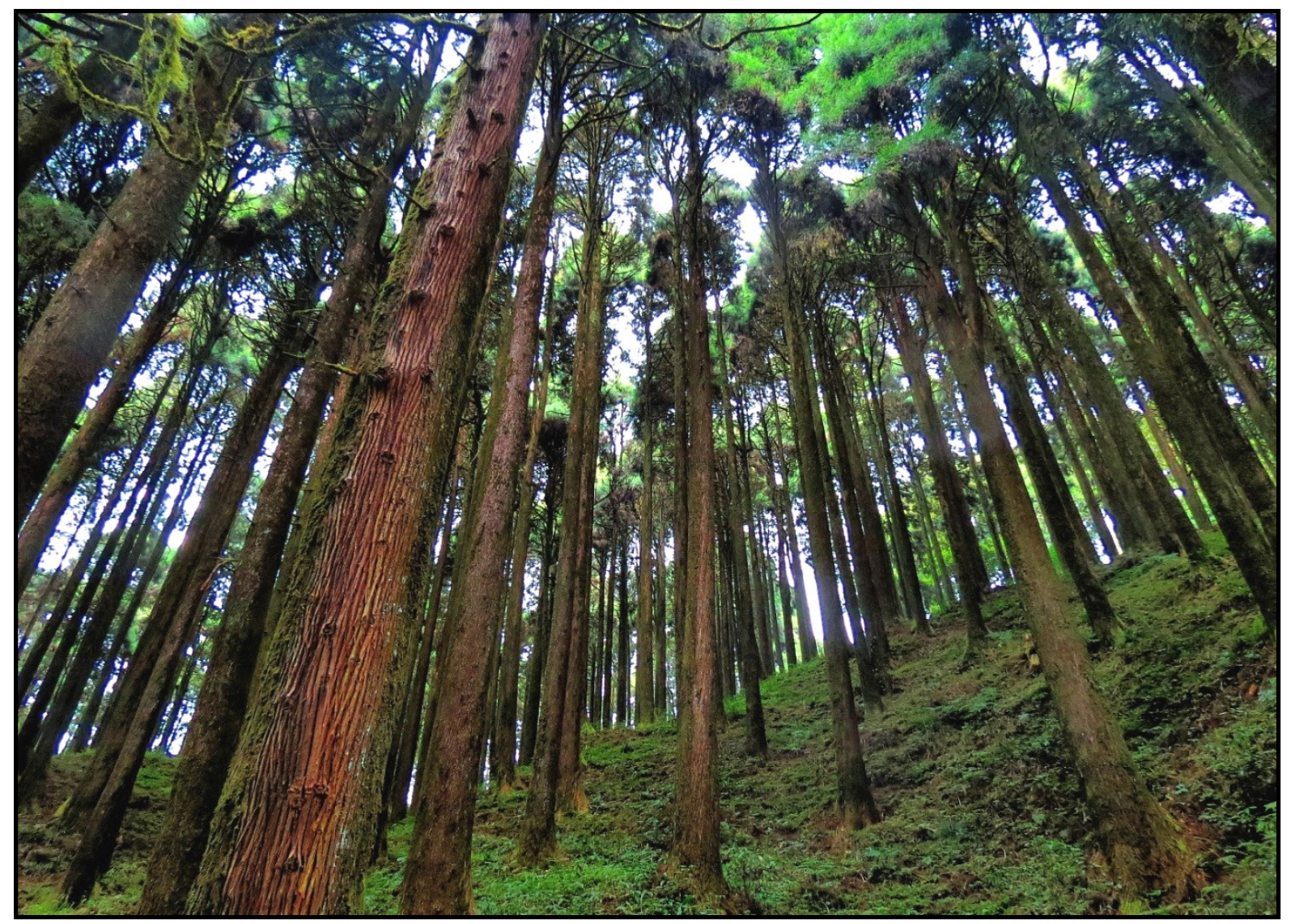

Figure 11. Pine forest in Senchal Wildlife Sanctuary at Chatakpur. 


\section{Faunal Diversity of SWS}

Wild pigs and barking deer are spread over Senchal wildlife sanctuary. Serow and goral occupy the untouched steep ridges and valleys while black bear belonging to Himalayas descend from higher altitudes and take rest during winter and autumn seasons. Leopard cat, jungle cat and leopard are seen in lower elevations of the forest. Apart from this Ant eater, flying squirrel, Indian civet, Assamese macaque and common Rhesus are also spotted here. The region of this sanctuary is very rich in bird life. Sunbirds, Babblers, Thrushes, Pigeons, Green, Imperial Pigeons, Hornbills, Fowl, Red jungle, Emerald Cuckoos, yellow necked wood pecker etc are spotted here [16].

\section{BIODIVERSITY LISTS OF SENCHAL WILDLIFE SANCTUARY}

Table 2. Medicinal plants of Senchal Wildlife Sanctuary [11].

\begin{tabular}{|c|c|c|c|}
\hline Scientific names & Local names & Parts used & Medicinal values \\
\hline Daphne cannabina & Kagata (Lokota) & $\begin{array}{l}\text { Roots and barks are } \\
\text { used for making papers }\end{array}$ & As antidote \\
\hline Eupatorium cannabinum & Banmara & Roots and leaves & $\begin{array}{c}\text { As antiseptic (to stop } \\
\text { blood) }\end{array}$ \\
\hline Selinum tenuifolium & Bhutkesh & Leaves and fruits & To cure skin diseases \\
\hline Acorus calamus & Bojo & Rhizome & $\begin{array}{c}\text { As sedative, laxative, } \\
\text { carminative }\end{array}$ \\
\hline $\begin{array}{c}\text { Xanthoxylum } \\
\text { acanthopodium }\end{array}$ & Boke timbur & $\begin{array}{c}\text { Plant parts including } \\
\text { fruits } \\
\end{array}$ & Fruits as appetizer \\
\hline Girardinia diversifolia & Bhangre sishnu & Roots and inflorescence & $\begin{array}{l}\text { Lowering blood } \\
\text { pressure and fever }\end{array}$ \\
\hline Astilbe rivularis & Buro okhati & $\begin{array}{l}\text { Leaves, roots and } \\
\text { rhizome }\end{array}$ & $\begin{array}{c}\text { For dysentery, blood } \\
\text { purifier }\end{array}$ \\
\hline Heracleum wallichi & Chimphing & $\begin{array}{l}\text { Inflorescence, fruit and } \\
\text { seed are used for } \\
\text { making local pickle }\end{array}$ & Influenza, bodyaches \\
\hline Pentapanax fragrans & Chinde & $\begin{array}{c}\text { Flower and young } \\
\text { shoots }\end{array}$ & $\begin{array}{c}\text { For stomach disorder } \\
\text { and weakness }\end{array}$ \\
\hline Swertia chirata & Chirauto & Shoot & $\begin{array}{c}\text { For fever, diabetes, } \\
\text { ulcer, asthma }\end{array}$ \\
\hline Mahonia nepalensis & Chutro & Berry and bark & $\begin{array}{l}\text { For dysentery and } \\
\text { urinary trouble }\end{array}$ \\
\hline Cynodon dactylon & Dubo & Plants and roots & In hysteria, epilepsy \\
\hline Hydrocotyl nepalensis & Dhungre jhar & Leafy shoots & $\begin{array}{l}\text { For throat infection, } \\
\text { pneumonia, T.B. }\end{array}$ \\
\hline Taxus baccata & Dhenre salla & Leaves & $\begin{array}{l}\text { Taxol extracted from } \\
\text { leaves to cure breast } \\
\text { cancer }\end{array}$ \\
\hline Rhododendron arboreum & Lali gurans & $\begin{array}{l}\text { For dysentery and } \\
\text { throat trouble }\end{array}$ & $\begin{array}{l}\text { For dysentery and } \\
\text { throat trouble }\end{array}$ \\
\hline Viscum album & Harchur & Whole plant & $\begin{array}{c}\text { Blood purifier, ulcer, } \\
\text { muscular pain }\end{array}$ \\
\hline Evodia fraxinifolia & Khanakpa & Fruit and plant & For typhoid \\
\hline
\end{tabular}




\begin{tabular}{|c|c|c|c|}
\hline Equisetum debile & Kukure jhar & Aerial parts & $\begin{array}{l}\text { Clotting agent used in } \\
\text { wounds, nose bleeding }\end{array}$ \\
\hline Rubia cordifolia & Majhito & Roots, shoots and fruits & For paralysis, jaundice \\
\hline Lycopodium clavatum & Nagbeli & Plants and spores & $\begin{array}{c}\text { For pulmonary disorder, } \\
\text { kidney disorder }\end{array}$ \\
\hline Juglans regia & Okhar & Bark & Used against cancer \\
\hline Bergenia ciliata & Pakhanbeth & Roots and rhizome & $\begin{array}{c}\text { Diarrhea, menstrual } \\
\text { disorder }\end{array}$ \\
\hline Panax pseudoginseng & Panch patey & Rhizome & $\begin{array}{c}\text { Weakness, diabetes, } \\
\text { asthma }\end{array}$ \\
\hline Urtica parviflora & Sishnu & Flower and young twig & $\begin{array}{l}\text { Blood pressure, liver } \\
\text { trouble }\end{array}$ \\
\hline Costus speciosus & Bet lowri & Rhizome & $\begin{array}{l}\text { Urinary infection, birth } \\
\text { control }\end{array}$ \\
\hline Nasturtium fontana & Seem rayo & Plant and stem & Blood cleaning agent \\
\hline Polygonum molle & Thotne & Young shoot & As astringent \\
\hline Artemisia vulgaris & Tite pati & Leaves and shoot & $\begin{array}{c}\text { Headache, nose } \\
\text { bleeding, skin diseases }\end{array}$ \\
\hline Clematis buchaniana & Pinasey lahara & Roots & For sinusitis \\
\hline Smilax zeylanica & Kukkur dayini & Roots & $\begin{array}{l}\text { For urinary problems } \\
\text { and dysentery }\end{array}$ \\
\hline
\end{tabular}

Table 3. List of tree species recorded in Senchal Wildlife Sanctuary [11, 12].

\begin{tabular}{|c|c|c|}
\hline Scientific Names & Local Names & Families \\
\hline Quercus spicata & Arakula & Fagaceae \\
\hline Prunus napaulensis & Arupatey & Rosaceae \\
\hline Aporosa dioica & Barkaunli & Euphorbiaceae \\
\hline Elaeocarpus sikkimensis & Bhadrasey & Elaeocarpaceae \\
\hline Magnolia champaca & Champ & Magnoliaceae \\
\hline Schima wallichii & Chilauney & Theaceae \\
\hline Garuga gamblei & Dabdabey & Burseraceae \\
\hline Syzygium cumini & Jamun & Myrtaceae \\
\hline Evodia fraxinifoila & Khanakpa & Rutaceae \\
\hline Machilus odoratissima & Lali kaulo & Lauraceae \\
\hline Nyssa javanica & Lekh Chilauney & Nyssaceae \\
\hline Ilex hookeri & Lissi & Aquifoliaceae \\
\hline Eriobotrya petiolata & Maya & Rosaceae \\
\hline Michelia lanuginosa & Phusrey champ & Magnoliaceae \\
\hline Brassaiopsis hispida & Puta & Araliaceae \\
\hline Cinnamonum tamala & Sinkoli & Lauraceae \\
\hline Michelia catcarthii & Titey champ & Magnoliaceae \\
\hline Quercus lamellosa & Buk & Fagaceae \\
\hline Pentapanax leschenaultii & Chindey & Araliaceae \\
\hline Machilus gammieana & Chipley kaulo & Lauraceae \\
\hline Cryptomeria japonica & Dhupi & Cupressaceae \\
\hline Leucoseptum canum & Ghurpis & Laminaceae \\
\hline Eurya japonica & Jhinguni & Pentaphylacaceae \\
\hline Acer campbelli & Kapasi & Sapindaceae \\
\hline
\end{tabular}




\begin{tabular}{|c|c|c|}
\hline Castanopsis hystrix & Katus & Fagaceae \\
\hline Machilus edulis & Kaulo & Lauraceae \\
\hline Symplocos theifolia & Kharaney & Symplocaceae \\
\hline Glochidion thomsonii & Lati kath & Phyllanthaceae \\
\hline Engelhardtia spicata & Mauwa & Juglandaceae \\
\hline Michelia exelsa & Mithey champ & Magnoliaceae \\
\hline Litsae polyantha & Paheley & Lauraceae \\
\hline Photinia integrifolia & Phalamey & Rosaceae \\
\hline Quercus lineate & Phalant & Fagaceae \\
\hline Cinnamonum impressinervium & Sissi & Lauraceae \\
\hline Endospermum chinensis & Seti Kath & Euphorbiaceae \\
\hline Tsuga brunoniana & Tengrey salla & Pinaceae \\
\hline Macaranga sp. & Malata & Euphorbiaceae \\
\hline Quercus lanceaefolia & Patle katus & Fagaceae \\
\hline Betula alnoides & Saur & Betulaceae \\
\hline Alnus nepalensis. & Utish & Betulaceae \\
\hline
\end{tabular}

Table 4. List of shrub species recorded in Senchal Wildlife Sanctuary $[11,12]$.

\begin{tabular}{|c|c|c|}
\hline Scientific names & Local names & Families \\
\hline Dichroa febrifuga & Basak & Saxifragaceae \\
\hline Litsaea lancifolia & Makkai kath & Lauraceae \\
\hline Acanogonum molle & Thotney & Polygonaceae \\
\hline Dhapney cannabina & Lokote & Berberidaceae \\
\hline Mahonia acantifolia & Chutro & Rosaceae \\
\hline Rubus ellipticus & Aiselu & Rosaceae \\
\hline Rubus lineatus & Aiselu & Rosaceae \\
\hline Rubus moluccanus & Bhotey pan & Caprifoliaceae \\
\hline Viburnum erubescens & Asarey & Saxifragaceae \\
\hline Astilbe rivularis & Buro Okhati & Myrsinaceae \\
\hline Maesa chisia & Bilaunae & Urticaceae \\
\hline Urtica parviflora & Sisnu & \\
\hline
\end{tabular}

Table 5. List of Herb species recorded in Senchal Wildlife Sanctuary [11, 12].

\begin{tabular}{|c|c|c|}
\hline Scientific names & Local names & Families \\
\hline Polygonum runcinatum & Rat naulo & Polygonaceae \\
\hline Strobilanthes $s p$. & & Acanthaceae \\
\hline Begonia $s p$. & Begonia & Begoniaceae \\
\hline Cissus elongata & Charcharey lahara & Vitaceae \\
\hline
\end{tabular}




\begin{tabular}{|c|c|c|}
\hline Cissus repanda & Pani lahara & Vitaceae \\
\hline Elatostema obtusum & Gogleto & Urticaceae \\
\hline Fern & Unio & \\
\hline Carex sp. & Harkata & Cyperaceae \\
\hline Hydrocotyle javanica & Dhungri jhar & Araliaceae \\
\hline Hypoestes triflora & & Acanthaceae \\
\hline Oplismenus sp. & Bansu & Poaceae \\
\hline Oxalis corniculata & Chari amilo & Oxalidaceae \\
\hline Pilea sp. & Chipley & Urticaceae \\
\hline Polygonum chinense & Lahare Ratnyaula & Polygonaceae \\
\hline Rubia manjit & Majito & Rubiaceae \\
\hline Selaginella sp. & & Selaginellaceae \\
\hline Seteria plicata & Dhoti sara & Poaceae \\
\hline Viola $s p$ & & Violaceae \\
\hline Anaphalis sp. & Bukki Phool & Asteraceae \\
\hline Bidens pilosa & Kuro jhar & Asteraceae \\
\hline Clematis sp. & Pinnasa lahara & Ranunculaceae \\
\hline Clinopodium umbrosa & & Lamiaceae \\
\hline Commelina sp. & & Commelinaceae \\
\hline Eupatorium adenophorum & Banmara & Asteraceae \\
\hline Fragaria $s p$ & Bhui aiselu & Rosaceae \\
\hline Lycopodium sp. & Nagbeli & Lycopodiaceae \\
\hline Ophiopogon sp. & Nakima & Convallariaceae \\
\hline Ophiorrhiza treutleri & Chire & Rubiaceae \\
\hline Pouzolzia hirta & Chiple & Urticaceae \\
\hline Rubus calycinus & Dhungri jhar & Rosaceae \\
\hline Stellaria sp. & & Caryophyllaceae \\
\hline
\end{tabular}

Table 6. Butterfly species in Senchal Wildlife Sanctuary [11].

\begin{tabular}{|c|c|c|}
\hline Common Names & Scientific Names & Families \\
\hline Common Grass Yellow & Eurema hecabe & Pieridae \\
\hline Dark Clouded Yellow & Colias fieldii & Pieridae \\
\hline Indian Cabbage White & Pieris canidia \\
\hline Bath White & Pontia daplidice & Pieridae \\
\hline Green Sapphire & Heliophorus sandrocles & Lycaenidae \\
\hline Pea Blue & Lampides boeticus & Lycaenidae \\
\hline Punchinello & Zemeros flegyas & Lycaenidae \\
\hline Lesser Punch & Dodona dipoea & Lycaenidae \\
\hline Common Woodbrown & Lethe sidonis & Nymphalidae \\
\hline
\end{tabular}




\begin{tabular}{|c|c|l|}
\hline Large Three-ring & Ypthima nareda & Nymphalidae \\
\hline Himalayan Five-ring & Ypthima sakra & Nymphalidae \\
\hline Painted Lady & Vanessa cardui & Nymphalidae \\
\hline Indian Tortoiseshell & Aglais cashmiriensis & Nymphalidae \\
\hline Chocolate Pansy & Junonia iphita & Nymphalidae \\
\hline
\end{tabular}

Table 7. Bird species in Senchal Wildlife Sanctuary [11].

\begin{tabular}{|c|c|}
\hline Common Names & Scientific Names \\
\hline Black-throated Tit & Aegithalos concinnus \\
\hline Green-tailed Sunbird & Aethopyga nipalensis \\
\hline Grey-bellied Cuckoo & Cacomantis passerinus \\
\hline Eurasian Treecreeper & Certhia familiaris \\
\hline Himalayan Flameback & Dinopium shorii \\
\hline Blue winged Laughing thrush & Garrulax squamatus \\
\hline Great Barbet & Megalaima virens \\
\hline Blue throated Barbet & Megalaima asiatica \\
\hline Scarlet Minivet & Pericrocotus flammeus \\
\hline Green-backed Tit & Parus monticolus \\
\hline Rosy Minivet & Pericrocotus roseus \\
\hline Yellow-billed Blue Magpie & Urocissa flavicollis \\
\hline
\end{tabular}

Table 8. Mammals of Senchal Wildlife Sanctuary [11].

\begin{tabular}{|c|c|}
\hline Common Names & Scientific Names \\
\hline Asiatic black bear & Ursus thibetanus \\
\hline Wild boar & Sus scrofa \\
\hline Large Indian Civet & Viverra zibetha \\
\hline Yellow throated Marten & Martes flavigula \\
\hline Common Leopard & Panthera pardus \\
\hline Himalayan Serow & Capricornis thar \\
\hline Himalayan Crestless Porcupine & Hystrix brachyuran \\
\hline Rhesus Macaque & Macaca mulatta \\
\hline Jungle cat & Felis chaus \\
\hline Asamese Macaque & Macacca assamensis \\
\hline Leopard Cat & Prionailurus bengalensis \\
\hline Himalayan Palm Civet & Paguma larvata \\
\hline Barking deer & Muntiacus muntjak \\
\hline Goral & Naemorhedus goral \\
\hline Indian Short-tailed Mole & Talpa micrura \\
\hline Indian Pangolin & Manis crassicaudata \\
\hline
\end{tabular}




\section{CONCLUSIONS}

Chatakpur have become the emerging tourist spot of West Bengal for pleasure trips, biological and geographical excursions and medical research works. In spite of getting so much attention in the recent time, the areas are not adequately developed. There is an urgent need for implementing sustainable management systems in the areas for the betterment of the socio-environmental structures. Some of the implementable management systems are as follows:

1. The ecotourism spots of Chatakpur are least advertised or given adequate publicity. Lack of systematic organization is another constraint of ecotourism in the study area. These issues should be addressed for the effective planning of sustainable ecotourism [17].

2. For reducing the water crisis in Chatakpur area, micro scale rainwater harvesting structures should be installed in the houses. Filtering systems should be provided to the local inhabitants so that they can use the rainwater for drinking purpose after purifying it.

3. Adequate health services should be provided to the local inhabitants of Chatakpur. Local Sub Health centers with doctors, nurses and basic medical facilities should be established in these areas.

4. Precaution should be taken for reducing the incidents of biopiracy, as these regions are very rich in medicinal plant resources. Government should take the initiatives for promoting and giving economic support to build up private nurseries where several varieties of important plant species can be preserved.

5. Local training centers should be established for teaching the local people about the importance of natural resources of Chatakpur. The initiatives of the local people can effectively protect the natural assets of those areas.

6. Portfolio of tourism products should be developed by utilizing its unique ecological assets [16]. As these areas are the attraction for tourists, development of handicrafts made from the forest bioresources could be beneficial for the economic development of the local communities.

7. West Bengal is the cultural capital of India. It has constantly produced thoughts, ideas and events which have brought forth freshness and rejuvenation in the society both in India and the world. The specific components of Cultural Tourism which can be implemented in these areas include Fairs and Festivals Tourism, Arts and Crafts Tourism and Village Tourism.

8. Tourism carrying capacity is defined as the maximum number of people that may visit the tourist destination without causing destruction of the physical, economic and socio cultural environment and an unacceptable decrease in the quality of visitors' satisfaction. The carrying capacity assessment and sustainability of tourism in the circuits identified is an important component of the ecotourism study as it will form the basis for resource allocation and future development [17]. The carrying capacity assessment should be done for Chatakpur, based on the number of tourists and their activities.

9. There is lack of gross knowledge among villagers on the advantages of afforestation in the Hill areas. Specific training and awareness efforts from the Forest Department have to be undertaken to educate people on the drawbacks of deforestation and the long term effects it has on climate. In the silviculture unit, the plant varieties should be increased and more modern methods of conversation should be implemented associated with gene banks and extensive databases. Ecological restoration should be done by restoring the damaged, degraded and areas destructed by landslides. Focus should be given on areas critically 
important to floral and faunal habitat, water catchments and areas important with social and cultural values.

10. Soil conservation is a set of management strategies for prevention of soil being eroded from the Earth's surface. Due to many anthropogenic activities, the land of Darjeeling is prone to landslide every year. WWF-India already initiated the protection of areas which are ecologically significance to the conservation of flora and fauna of the region through a project called SERVE. Vegetative control measure of soil conservations should be adopted to protect further damage of land at and around the protected areas of Senchal Wildlife Sanctuary. Promotion and implementation of vermicomposting techniques in this area can maintain the soil structure, agricultural productivity and waste reduction [18].

11. Rhododendron is one of the significant species of Darjeeling hills [15]. It plays an important role in the ecosystem of theses region. But in recent years, the species is threatened due to deforestation and loss of habitat. Rhododendron conservation by educating people and by raising saplings could manage and restore these species in Senchal Wildlife Sanctuary.

12. Organic farming is one of the several approaches found to meet the objectives of sustainable agriculture. Organic farming is a production system that sustains the health of soils, ecosystem and the people. Organic farming works in harmony with the nature rather than against it. It relies on ecological processes adapted to local conditions, rather than the use of inputs with adverse effects in the long run. Encouraging and supporting the farmers towards Organic farming in Chatakpur area should be done by government initiatives.

13. The effects of climate change are more severe in the Himalayas compared to the other regions [19]. The annual and seasonal temperature trends in the Kanchenjunga landscape indicate an increase at the rate $0.01-0.015{ }^{\circ} \mathrm{C} /$ year, with higher altitudes experiencing greater warming [20]. Likewise, among the administrative units, Darjeeling was the most vulnerable compared to Sikkim, eastern Nepal and western Bhutan. Extensive studies on the effects of climate change on Chatakpur should be done, as this zone represents one of the richest biodiversity zones of India.

14. Like any other protected area in India, the forests of Chatakpur suffer from illegal cattle grazing, firewood collection, encroachment on the fringes and poaching. However, due to inaccessibility and difficult terrain, the biotic pressures are still not very acute. More intense survey works and management practices should be done for mitigating the anthropogenic threats.

15. Separate waste collection and disposal system should be operated by the government for safeguarding the sensitive ecosystems of the areas. Effective management design should be done for plastic wastes generated in these areas.

16. The vehicles used in the areas should be monitored regularly so that the vehicular pollution could be checked in the areas. Installation of the modern devices in the vehicles for pollution control should be done and routine checking system should be implemented.

17. To reduce the pressure on the forest and the drudgery to which women are subjected due to use of smoke producing "chullas", an alternative fuel policy should be evolved and implemented. Large scale installation of solar panels in these areas would be beneficial. Biogas is a cheap, pollution free alternative energy source. It can also reduce the annual emission of $\mathrm{CO}_{2}$ from households. One biogas plant can save approximately 2 tons of fuel wood, 0.8 tons of agricultural wastes and 50 litres of kerosene per household per person. Implementation of biogas plant in Chatakpur area can reduce the pressure on fuel wood.

18. Proper land use pattern should be done, keeping the socio-economic and ecological parameters in view. 


\section{References}

[1] Government of West Bengal, India. North Bengal: Forestry operations and tourism. Accessed on 2nd May, 2014. Accessed from: http://wb.gov.in/.

[2] Chatakpur eco village. Accessed on $12^{\text {th }}$ December, 2014. Accessed from: http://chatakpur.toursss.com/aboutus.php.

[3] Chatakpur. North Bengal Development Department, Govt. of West Bengal. Accessed on $12^{\text {th }}$ December, 2014. Accessed from:

http://wbnorthbengaldev.gov.in/HtmlPage/chatakpur.aspx.

[4] Bhattacharya S., Shome A., Sarkar S., Purkait D., Ghosh U. C., International Letters of Social and Humanistic Sciences 17(2) (2014) 102-118.

[5] Bhattacharya S., Ghosh U. C., International Letters of Natural Sciences 18 (2014) 9-26.

[6] Earthquake. West Bengal Disaster Management Department. Accessed on $12^{\text {th }}$ December, 2014. Accessed from: http://wbdmd.gov.in/Pages/Earthquake.aspx.

[7] WPC recommendation 20. 2003. Preventing \& mitigating human-wildlife conflicts. IUCN-World Park Congress.

[8] Lamarque,F., et.al. 2008 Human-Wildlife Conflict in Africa-An Overview of Causes, Consequences and Management Strategies. Working Paper of IFCW and FAO,Rome.

[9] Zubri, C. and Switzer, D. 2001. Crop raiding primates: searching for alternative human ways to resolve conflict with farmers in Africa. People and Wildlife Initiative Wildlife Conservation Research Unit, Oxford University.

[10] Myers, N., R. A. Mittermier, C. G. Mittermier, G. A. B. da Fonseca, Kent, J., Nature 403 (2000) 853-858.

[11] WWF. 2012. Status and Distribution of Asiatic Black Bear and the Status of HumanBear Conflict at Senchal Wildlife Sanctuary Darjeeling, West Bengal, India. WWF-India and West Bengal Forest Department, Wildlife Division I.

[12] Basu Roy, A. 2010. Status survey of butterflies at Senchal Wildlife Sanctuary. Nature Mates-Nature Club, Kolkata, India.

[13] ICIMOD. 2012. Mainstreaming Community-Based Conservation in a Transboundary Mountain Landscape: Lessons from Kangchenjunga. International Centre for Integrated Mountain Development, Kathmandu, Nepal.

[14] Senchal Wildlife Sanctuary. HKH Conservation Portal. Accessed on $12^{\text {th }}$ December, 2014. Accessed from: http://hkhconservationportal.icimod.org/PA.aspx?ID=5

[15] ICIMOD. Plant Resources in the Protected Areas and Proposed Corridors of Darjeeling, India. Accessed on $12^{\text {th }}$ December, 2014. Accessed from: http://lib.icimod.org/record/26260/files/c_attachment_520_4759.pdf.

[16] Senchal Wildlife Sanctuary. India mapped: Wildlife Sanctuaries in India. Accessed on $12^{\text {th }}$ December, 2014. Accessed from: http://www.indiamapped.com/wildlife-sanctuariesin-india/himachal-pradesh-senchal-wildlife-sanctuary/.

[17] Karmakar M., Tourismos 6(1) (2011) 251-270. 
[18] WWF. 2009. Annual Activity Report, 2008: Project SERVE. Darjeeling Field Office, WWF-India.

[19] IPCC. 2007. Climate Change 2007: Impacts, adaptation and vulnerability. Cambridge University Press, Cambridge, UK.

[20] Singh S.P., Bassignana-Khadka I., Karky B.S., Sharma E. (2011). Climate Change in the Hindu Kush-Himalayas: The State of Current Knowledge. International Centre for Integrated Mountain Development, Kathmandu, Nepal. 